\title{
O desejo do psicanalista como operador ético da psicanálise
}

\author{
Júlio Eduardo de Castro \\ Universidade Federal de São João Del-Rei, São João Del Rei, MG, Brasil
}

Resumo

\begin{abstract}
Neste artigo, resultado de estudos realizados no doutorado e pós-doutorado, é investigada, no ensino de Lacan, a participação e importância do psicanalista (e de seu desejo) como o agente (suporte do objeto a) que opera a ética da psicanálise. Com o objetivo de aprofundar as relações dessa ética (suas premissas e princípios) ao proceder do psicanalista - sua escuta e atos -, merece destaque a expressão usada por Lacan: o desejo do psicanalista. Esta expressão nos mostrou haver uma consistência elementar entre o campo da ética e a operacionalização da psicanálise por meio de seu agente/suporte transferencial, o psicanalista, durante a condução do tratamento, naquilo que o próprio Lacan formulou, em seu ensino, como essencial à formação do psicanalista: a psicanálise em intensão. Lateralmente, são abordadas expressões correlatas, e nem por isso sem importância, no campo da ética da psicanálise: o ato do psicanalista, o discurso do psicanalista e o saber do psicanalista.
\end{abstract}

Palavras-chave: ética da psicanálise; transmissão da psicanálise; desejo do psicanalista.

\section{The psychoanalyst's desire as ethical operator of the psychoanalysis}

\begin{abstract}
In this article, the result of studies carried out during PhD and postdoctoral researchs, it is investigated, in the Lacan's teaching, the psychoanalyst's participation and importance (and of your desire) as the agent (supports of the object the) that operates the ethics of the psychoanalysis. With the objective of deepening the relationships of that ethics (its premises and principles) when proceeding of the psychoanalyst - its listens and acts - we highlighted the expression used by Lacan: the psychoanalyst's desire. This expression revealed an elementary consistence between the field of the ethics and the operation of the psychoanalysis through its agent/transferential support, the psychoanalyst, during the conduction of the treatment, in what Lacan himself formulated during his teaching as essential to formation of the psychoanalyst: psychoanalysis in intensity. Laterally, correlated and important expressions are discussed in the field of psychoanalysis ethics: the psychoanalyst's act, the psychoanalyst's discourse and the psychoanalyst's knowledge.
\end{abstract}

Keywords: ethics of the psychoanalysis; transmission of the psychoanalysis; psychoanalyst's desire.

\section{Introdução: antecedentes e metodologia}

Este artigo é um dos resultados dos estudos teóricos realizados para minha tese de doutorado, com o objetivo de pesquisar, no ensino de Lacan, algumas referências marcantes para o campo da ética psicanalítica. Foi possível constatar que, para tornar presente esta ética, o psicanalista opera com o seu desejo, o seu ato, o seu discurso e o seu saber. De modo que, se a ética é da psicanálise, fazê-la presente nas situações é função do psicanalista. Ele é então aquele que operacionaliza, por meio de seu desejo, a ética da psicanálise nas mais variadas situações (clínica e institucional) e manifestações subjetivas (individual e coletiva). Além disso, verificamos que Lacan, muitas vezes, ao se referir ao campo da ética da psicanálise, não raro faz uso de alguma destas quatro expressões: o desejo do psicanalista, o ato do psicanalista, o discurso do psicanalista e o saber do psicanalista. Por isso decidimos examinar algumas das referências bibliográficas a esses quatro termos ou expressões a partir do ensino nos legado por Lacan em seus seminários e escritos, não somente com a intenção de destacar a conexão desses "operadores" da psicanálise com o campo da ética, mas principalmente de fazer aí um primeiro mapeamento dessas mesmas referências, com a intenção de levantar questões e hipóteses que estimulem pesquisas futuras sobre tal temática. Isso porque a abordagem da ética da psica-

\footnotetext{
^Endereço para correspondência: Universidade Federal de São João Del-Rei, Departamento das Psicologias, Centro Científico. Praça Dom Helvécio, 74 - sala 2.21 - Dom Bosco. Cep: 36300-000 - São João Del Rei, MG - Brasil. E-mail: julioecastro@mgconecta.com.br

Os dados completos dos autores encontram-se ao final do artigo.
}

nálise, principalmente quando examinada por meio dos aqui chamados "operadores", nos mostrou ser um veio promissor de pesquisa.

Ao pesquisarmos o ensino lacaniano da psicanálise (CASTRO, 2006), encontramos essas quatro expressões como referências inequívocas à ética da psicanálise. Lacan não se cansou de mencioná-las em vários momentos de seu ensino, e sempre as subordinando ao psicanalista. Por mais que, ao mencioná-las, ele use o qualificativo de posse como contração da preposição "de" com o artigo "o" - desejo, ato, discurso e saber "do" psicanalista -, não é bem disso que se trata, pois, como veremos, se há posse de algo por parte do psicanalista, ela se apresenta antes de tudo como despojamento subjetivo que abre a perspectiva a uma escuta limpa de preconceitos e, por isso mesmo, de ideais e de expectativas. De modo que a perspectiva ética da psicanálise - seja no campo do ensino, seja no campo de origem (a clínica das neuroses) - foi uma preocupação incessante de Lacan, principalmente por sua ligação com a formação do psicanalista. Esta formação deveria tê-lo destituído de algo de suas identificações e certezas subjetivas, bem como de alguns dos ideais do eu e do Outro. Essa destituição pode ser entendida como o que abriria a sua escuta e afiaria os seus atos durante a direção do tratamento/cura.

O ponto de partida ou antecedentes do estudo teórico aqui realizado foi, então, o campo do ensino da psicanálise, que nos levou a concluir que 
[...] quando os operadores éticos da psicanálise participam ou mesmo determinam o seu ensino, este nunca será uma frente de resistência onde o eu possa alojar-se. Contrariamente, quando o ensino da psicanálise resiste às influências do ato, do saber e do desejo do psicanalista, ele se transforma em porta-voz do sintoma daquele que tenta ensinar e/ou da instituição onde essa tentativa é feita, contando, para tal, com aquilo que, no discurso universitário, favorece a des-subjetivação do saber e a não-implicação do sujeito do inconsciente. Já o ensino orientado pelos operadores éticos da psicanálise é uma via aberta às surpresas - que têm no objeto $a$ a causa - e às contingências que, como tais, trazem a oportunidade de escrita/literalização do real. No ensino em que vigora o poder do saber, altamente conveniente ao eu, a tendência é cair na mesmice, na burocracia e no tédio, visto serem prerrogativas do eu a ordem, a obstinação e a parcimônia. Servir-se do contingente e conduzir-se mobilizado pelo objeto $a$ são, por outro lado, a marca do discurso psicanalítico, justamente por fazer da falta, já desvelada, motivo de entusiasmo para com a causa-do-desejo (CASTRO, 2006, p. 153).

Entretanto, logo após tal conclusão, tínhamos a sensação de que ainda havia algo a mais a ser pesquisado... Notadamente, era algo para-além do problema de pesquisa do qual nos ocupávamos naquele tempo: o ensino da psicanálise. Pesquisando-o, deparamo-nos com um campo de problemas éticos que, inexoravelmente, determina todo e qualquer ensino da psicanálise. Se pode haver transmissão da psicanálise sem que necessariamente haja ou tenha havido ensino, a recíproca, contudo, não é verdadeira. Um ensino da psicanálise desvinculado da ética do desejo não merece o qualificativo de psicanalítico. Pode no máximo ser instruções sobre a doutrina, entretanto, esvaziada de seu espírito. A necessidade de consonância do ensino da psicanálise com a ética que a distingue foi, portanto, um dos pontos de chegada de minha tese de doutoramento. Nela, quando passamos a considerar mais detidamente as impossibilidades inerentes ao ensino da psicanálise, desembocamos no veio ético do psicanalista (o des-ser) - erguido já desde a psicanálise em intensão, ou seja, a análise do próprio analista - e que o impulsiona a agir segundo a política da falta-a-ser, princípio regulador do desejo que, mesmo em situação de ensino, nunca deveria ser por ele esquecido ou mesmo negligenciado.

As quatro expressões acima citadas surgiam sempre que Lacan fazia referência direta ou indireta ao campo da ética da psicanálise - e a seu agente: o psicanalista como semblante do objeto $a$. Isso nos levou a formular essas quatro expressões, extraídas do ensino de Lacan, como "os operadores éticos do psicanalista". ${ }^{1}$ Chamá-las e agrupá-las assim, sob um único e mesmo designador, foi, entretanto, um achado que não fez cessar a ânsia de pesquisar, no ensino de Lacan, os momentos de seus aparecimentos e, ainda, o contexto em que surgiram. Para

\footnotetext{
'Adotamos o conceito de "operador" segundo o seu emprego em análise matemática - ou seja, como símbolo de uma operação que se efetua sobre uma variável ou sobre uma função - no caso, a presença real do psicanalista como suporte de $a$ - e não segundo o seu uso em cibernética, onde é usualmente empregado para se referir às comunicações e ao sistema de controle das máquinas, uso em que o termo operador se reduz ao registro do Simbólico. Por isso, nossa concepção de "operador" (ainda mais quando acompanhado do complemento "ético do psicanalista") é - justo por pressupor como necessária ao discurso analítico a função de semblante do objeto $a(a \rightarrow \$)$ - muito mais ampla que a acepção cibernética.
}

tal, foi necessário rastrear os usos e os empregos feitos por Lacan dessas quatro expressões. Nesse rastreamento, foi importante ter considerado o momento e o contexto em que Lacan as utilizou, para aí ter verificado que o que estava em jogo era a dimensão ética, dimensão essa em que se encontram os princípios fundamentais de tudo aquilo que se designa "transmissão em/da psicanálise".

No conjunto, entendemos essas quatro expressões como referências lacanianas ao modo como o psicanalista exerce/opera a ética da psicanálise ao fazer existir o inconsciente em situação clínica, ou seja, as entendemos como facetas de um mesmo efeito: a produção de um psicanalista. $\mathrm{O}$ ato, o discurso e o saber do psicanalista são, a nosso ver, juntamente com o desejo do psicanalista, efeitos de uma psicanálise, e como tais determinam a posição ética do psicanalista, quer em situação de tratamento ou em qualquer outra: de ensino, de pesquisa, de extensão universitária ou institucional. Sendo efeitos de uma psicanálise levada até seu último termo, tornam-se, por isso mesmo, os operadores éticos do psicanalista feitos presentes nessas mesmas situações. Este foi o postulado da pesquisa da qual este artigo é um dos resultados.

Posteriormente, no pós-doutorado, o nosso problema de pesquisa foi formulado da seguinte maneira: Em que momentos, como e por que as expressões "desejo do psicanalista", "saber do psicanalista", "discurso do psicanalista" e "ato do psicanalista" surgem e se firmam como coordenadas éticas no ensino de Lacan?

Nossa hipótese foi a de que nenhuma dessas expressões - justamente por seu conteúdo comum não se reduzir ao registro do Simbólico e nem por ele ser plenamente recoberto - mereceu o qualificativo de conceito. Por isso, elas são aqui tratadas como operadores, ou seja, como coordenadas teóricas e éticas a guiarem o psicanalista na direção do tratamento. Daí o objetivo geral de explicitar - a partir de uma leitura orientada dessas expressões extraídas do ensino de Lacan - a presença inerente e necessária de uma vertente ética própria à psicanálise.

Com a direção teórico-metodológica já estabelecida - e com o postulado acima fundado como marco zero, nos guiamos pelo seguinte problema de pesquisa: pela alta densidade semântica presente nesses termos ou expressões, ou seja, por Lacan concentrar nesses nomes a operacionalização da ética do psicanalista na clínica e na cultura - e pela importância que a ética da psicanálise tem, como pano de fundo ou não, nas pesquisas feitas no campo psicanalítico -, será plausível extrair consequências ético-teóricas dessas referências lacanianas? Qual o valor dessas quatro expressões ou termos para o campo ético da psicanálise?

A passagem atenta por essas referências nos forneceu ainda subsídios para entendê-las como coordenadas éticas a serem levadas em conta, além do campo clínico, mesmo nas pesquisas acadêmicas futuras em psicanálise. Se a pesquisa em psicanálise não se sustenta desvinculadamente da vertente ética, a composição dessas coordenadas ético-teóricas pretende contribuir, ainda, para a orientação de futuros pesquisadores, principalmente no 
contexto da pesquisa universitária. Isso devido à ubiquidade do desejo do psicanalista no campo psicanalítico, inclusive no contexto da pesquisa universitária. Essa ubiquidade aponta para a necessidade de que as pesquisas universitárias sobre psicanálise não estejam em dissonância com os princípios éticos elementares decorrentes do estabelecimento da doutrina psicanalítica freudo-lacaniana. De modo que toda pesquisa que pretenda se qualificar como psicanalítica deveria levar em conta tanto os pressupostos teóricos (conceitos fundamentais da psicanálise) como os princípios éticos neles entrelaçados.

A seguir, apresentaremos e comentaremos, resumidamente, algumas das principais referências lacanianas ao desejo do psicanalista. Esta expressão é aqui destacada, em detrimento das três demais, por razões de espaço editorial, e cumpre a função de apreciar, como necessário, o veio ético inerente à conduta do psicanalista durante a direção do tratamento.

\section{O desejo do psicanalista}

Esta expressão tem sua primeira aparição, no ensino de Lacan, em O Seminário 6: O desejo e sua interpretação (LACAN, 1959-1960/1990?a) - mais especificamente na lição de 01/07/1959. E tal referência surge em uma situação de ensino em que Lacan põe frente a frente o desejo (como desejo do Outro) e o desejo do psicanalista.

O problema da análise é justamente o desejo que o sujeito tem por reencontrar, que é este desejo do Outro, nosso desejo, este desejo que está presente somente no que o sujeito supõe que o demandamos, este desejo se encontra numa situação paradoxal... Como pode esta situação ser sustentada. Ela não pode ser seguramente sustentada senão por meio da manutenção de um artifício que faz parte de toda a regra analítica [...]. O essencial da análise dessa situação em que nos encontramos, ser aquele (o analista) que se oferece como suporte para todas as demandas e que não responde a nenhuma (LACAN, 1959-1960/1990?a, lição 27 de 01/07/1959).

Na sequência deste mesmo Seminário, Lacan relembra aos presentes a essência vazia do desejo - fator este que jamais deveria ser desconsiderado pelos psicanalistas. Presentificar o vazio é, portanto, uma função inerente e necessária ao desejo do psicanalista. Podemos formulá-la com o seguinte lema: "Nada desejar para o sujeito/ psicanalisante, deixando-o assim a desejar". Lacan aponta, então, para algo aquém do desejo do Outro, para a vacuidade constitutiva do desejo enquanto a verdadeira mola ética que sustenta a regra fundamental da psicanálise e que, por decorrência, move o processo psicanalítico.

Curiosamente, a citação acima - além de vir acompanhada da articulação do desejo como "falta-a-ser", característica marcante da política do psicanalista (LACAN, 1958/1998a) - é seguida pela dedicação de várias linhas ao "corte" como modo de o psicanalista, em posição de objeto, intervir apontando o vazio (e sua falta constitutiva), e assim manter aberta a perspectiva do desejo.

É que nós não devemos fazer uma parte essencial, nisto que é imanente a toda a situação mesma enquanto nosso desejo deva limitar-se a este vazio, a este lugar que deixamos ao desejo, para que se situe ali o corte? No corte que é sem dúvida o modo mais eficaz de intervenção e de interpretação analítica. E é uma das coisas sobre as quais deveríamos insistir mais, neste corte que fazemos mecânico, que fazemos limitado a um tempo pré-fabricado. É um dos métodos mais eficazes de nossa intervenção, é também um dos que deveremos usar mais. Mas neste corte há algo, esta mesma coisa que temos aprendido a reconhecer sob a forma de objeto fálico latente em toda relação de demanda, como significante do desejo (LACAN, 1959-1960/1990?a, lição 27 de 01/07/1959).

A importância dada ao desejo, como fundado na falta, e ao corte, como modo de apontá-la na relação com o desejo do Outro, são então termos que compõem o ponto/eixo denominado por Lacan de "o desejo do psicanalista", ponto esse em torno do qual Lacan já estabelece algumas coordenadas éticas da psicanálise. E este desejo do psicanalista Lacan (1959-1960b/1988), no Seminário 7: A ética da psicanálise, o localiza para-além do desejo do Outro, justamente por ser ele acompanhado do qualificativo "advertido". Para Lacan, portanto, o desejo do psicanalista é, diferentemente do desejo do Outro, tido como advertido. Ele atribui, assim, uma posição de objeto, porém diferenciada, ao lugar do psicanalista.

Contudo, o que dizer do emprego desse adjetivo (advertido) como característico do desejo do psicanalista? Certamente esse caráter advertido do desejo do psicanalista é o resultado do que restou da destituição subjetiva promovida pelo que foi sua própria análise. Podemos ainda pensá-lo como "advertido", porque já atravessado pelos enganos e desenganos do psicanalista relativos à transferência e a seu pivô, o sujeito-suposto-saber.

A formação do psicanalista exige que ele saiba, no processo em que conduz seu paciente, em torno do quê o movimento gira. Ele deve saber, a ele deve ser transmitido, e numa experiência, aquilo de que ele retorna. Esse ponto-eixo é o que eu designo - de um modo que, penso, lhes parece já suficientemente motivado, mas que, espero, à medida do nosso progresso, lhes parecerá cada vez mais claro, cada vez mais necessário - é o que designo pelo nome de desejo do psicanalista (LACAN, 1964/1979, p. 218-219, grifos nossos).

O desejo do psicanalista é, inicialmente no ensino de Lacan, portanto, situado como um ponto-pivô, ponto-eixo em torno do qual deve girar a ética da psicanálise.

Já no Seminário 12: Problemas cruciais para a psicanálise (LACAN, 1964-1965/1990?c), o autor, referindo-se à "identificação", faz um longo percurso para contrapô-la [a identificação] ao desejo do psicanalista. E o contexto do qual se serve para realizar tal contraposição é o tratamento psicanalítico. Lacan, nessa época, estava envolvido em denunciar os desvios da prática psicanalítica, principalmente os desvios que se sustentavam na premissa de que o psicanalista deveria ser um suporte identificatório para os seus psicanalisandos. Oferecer-se como Ideal ao Eu do psicanalisando era, então, o lema de uma prática que ficou conhecida como "Psicologia do Eu" - prática essa que sustentava o que deveria ser o final de todo e qualquer tratamento psicanalítico: a identificação do psicanalisando ao psicanalista. E foi, portanto, para contrapor-se a esta concepção do que seria o final 
de análise que Lacan cunhou o "desejo do psicanalista". Reler a pulsão freudiana como um conceito fundamental da psicanálise, desvinculando-o de vez de qualquer leitura biologizante (LACAN, 1964/1998c), fez parte da estratégia lacaniana na denúncia desses desvios - já que a Psicologia do Eu propunha a existência de um tipo de amor, chamado de genital, pressuposto no conceito de pulsão genital. Levar o sujeito em análise ao amor genital - servindo-se para tal da identificação do "eu forte do psicanalista" - era, portanto, uma concepção de cura que exigia a retomada dos princípios éticos freudianos que deveriam nortear a ação do psicanalista: daí a importância da criação do desejo do psicanalista. Desejo este que faria, portanto, oposição a todo e qualquer tratamento ancorado na identificação com o psicanalista.

Afirmando que "[...] o desejo vem do Outro, e o gozo está do lado da Coisa", Lacan (1964/1998c, p. 867-868) se pergunta qual seria a finalidade da análise e o papel aí do desejo do psicanalista:

Então, qual é a finalidade da análise, para além da terapêutica? Impossível não distingui-la desta quando se trata de produzir um analista. Pois, como dissemos sem entrar na mola da transferência, é o desejo do analista que, em última instância, opera na psicanálise.

No Seminário 7: A ética da psicanálise (LACAN, 1959-1960/1988, p. 360), o desejo do psicanalista é formulado como para-além da demanda de felicidade, e até mesmo de qualquer promessa:

O que pode ser um tal desejo, propriamente falando, o desejo do analista? Desde já podemos no entanto dizer o que ele não pode ser. Ele não pode desejar o impossível. Vou lhes dar um exemplo disso na definição, a mais firme, que um autor conseguiu confiar antes de desaparecer, de uma função que lhe parece essencial na relação dual com o analista, relação que existe uma vez que respondemos à demanda de felicidade, mas que não esgota a análise. Essa função, que é aquela dita da distância, é definida nestes termos - a hiância que separa a maneira pela qual o sujeito expressa seus drives instintuais da maneira pela qual poderia expressá-los se o processo de arrumar e de ajeitar suas expectativas não interviesse.

Lacan encerra esse Seminário sobre a premissa ética da psicanálise: "Agiste em conformidade com teu desejo?" - e, para tal, a recorrência ao conceito de pulsão (e de sua satisfação) foi indispensável, bem como a afirmação de que a psicanálise não deve trabalhar a favor do "serviço dos bens" e de sua "racionalização moralizante".

A ética da psicanálise não é uma especulação que incide sobre a ordenação, a arrumação do que chamo de serviço dos bens. Ela implica, propriamente falando, a dimensão que se expressa no que se chama de experiência trágica da vida. É na dimensão trágica que as ações se inscrevem, e que somos solicitados a nos orientar em relação aos valores (LACAN, 1959-1960/1988, p. 375-376).

\footnotetext{
O "serviço dos bens" mencionado por Lacan refere-se aos bens privados, aos bens de família, aos bens da casa, aos bens do ofício, aos bens da profissão e aos bens da Cidade.
}

A dimensão trágica da experiência psicanalítica é, portanto, outro elemento que serve de contraponto ao serviço dos bens e à finalidade terapêutica da psicanálise. E seria justamente por meio do desejo do psicanalista - em sua proximidade à "experiência trágica da vida" - que haveria uma chance de uma ética sustentada no desejo (do Outro e para além dele), e não em qualquer promessa de felicidade, de cura ou de bem-estar.

Entretanto, é no Seminário 8: A transferência (LACAN, 1960-1961/1992a) que encontramos inúmeras referências ao desejo do psicanalista. E todas elas são formuladas para manifestar a aversão de Lacan à referência diádica (ou interpessoal) na abordagem da transferência. Ele já havia nos lembrado que o psicanalista deve pagar algo para cumprir sua função: com palavras, na interpretação, e com sua pessoa, já que "pela transferência ele é literalmente despossuído dela" (LACAN, 19591960/1988, p. 349). Ao focalizar a atopia de Sócrates no mundo grego - o fato de ser Sócrates tão insituável e inclassificável quanto deveria ser o psicanalista -, Lacan examina a complexidade da transferência, localizando-a para além do psicanalisando. Recorre, então, uma vez mais, ao desejo do psicanalista.

Não basta falar agora de katarsis, purificação, se posso dizer, do grosso do inconsciente no analista. Tudo isso fica muito vago. É preciso fazer justiça aos analistas que, há muito tempo, não se contentam com isso. Não para criticá-los, mas para compreender com que obstáculo estamos lidando, é preciso perceber que não estamos nem no começinho daquilo que, no entanto, se poderia articular tão facilmente, sob forma de questão, com referência ao que deve ser obtido em alguém para que ele possa ser um analista. Dizem: é preciso que ele saiba agora um pouquinho mais da dialética de seu inconsciente. Mas o que sabe ele disso exatamente, afinal? E, principalmente, até onde o que ele sabe disso precisou ir, com relação aos próprios efeitos do saber? E formulo para vocês, simplesmente, esta questão: o que deve restar de suas fantasias? Sabem que sou capaz de ir mais longe e de dizer sua fantasia, se é que existe uma fantasia fundamental. Se a castração é aquilo que se deve aceitar no último termo da análise, qual deve ser, então, o papel da cicatriz da castração no eros do analista? (LACAN, 1960-1961/1992a, p. 108-109, grifos do autor).

A esta questão Lacan (1960-1961/1992a, p. 109) responde contestando as referências à relação médico-paciente ou a qualquer outra díade como modo de abordagem do desejo do psicanalista:

Trata-se, portanto, para nós, de tentar articular e situar o que deve ser, o que é fundamentalmente o desejo do analista - e isso, segundo balizas que podem, a partir de uma topologia já esboçada, ser designadas como coordenadas do desejo, pois não podemos encontrar nossas balizas idôneas referindo-nos às articulações da situação para o terapeuta ou para o observador, e em nenhuma das noções de situação tais como nos são expostas numa fenomenologia que se elabora à nossa volta. Pois o desejo do analista não é tal que possa se bastar por uma referência diádica. Não é a relação com o paciente que pode, por uma série de eliminações e excursões, nos dar a sua chave. Trata-se de algo mais intrapessoal. Isso também não quer dizer que o analista deva ser um 
Sócrates, nem um puro, nem um santo. Sem dúvida, esses exploradores que são Sócrates, ou os puros, ou os santos, podem nos dar algumas indicações relativas ao campo que está em questão. Isso não é dizer bastante - pensando bem, é a este campo que referimos toda a nossa ciência, entendo experimental. Mas é justamente devido ao fato de que é por meio deles que a exploração é feita que possamos talvez definir, e em termos de latitude e de longitude, as coordenadas que o analista deve ser capaz de atingir para, simplesmente, ocupar o lugar que é o seu, o qual se define como aquele que ele deve oferecer vago ao desejo do paciente para que se realize como desejo do Outro.

E é justamente o desejo como desejo do Outro que se desdobra na transferência, na forma de amor, durante o percurso analítico: o sujeito passa da posição de érôménos (sujeito amado) à posição de érastès (objeto amante), a chamada "metáfora do amor", segundo Lacan - que não vê nessa passagem nenhuma contraindicação, já que faz parte, desde o começo das análises, do chamado amor de transferência. A contraindicação para a psicanálise, Lacan (1960-1961/1992a, p. 195) a localiza, pelo contrário, do lado do psicanalista, nitidamente quando este lança seu próprio agalma sobre o analisando:

[...] basta supor que o analista, mesmo à sua revelia, coloque por um instante seu próprio objeto parcial, seu agal$m a$, no paciente com quem está lidando. Aí, com efeito, se pode falar de uma contra-indicação, mas como vêem, nada menos que localizável - ao menos enquanto a situação do desejo do analista não é explicitada.

Com efeito, Lacan aí reafirma - usando a palavra agalma para se referir à face brilhante do objeto $a-\mathrm{a}$ importância de o psicanalista não projetar sobre o analisando tal objeto, causa de seu próprio desejo. Isto seria conduzir a análise segundo os ideais do Outro [I(A)] - o que estimularia, por efeito, a identificação do analisando com o psicanalista. Uma vez mais surge aqui a preocupação de Lacan com as análises dirigidas pelo serviço dos bens e com a identificação (cultural e subjetiva) aí promovida.

As relações estreitas da identificação com a angústia são examinadas por Lacan (1962-1963/2005) no Seminário 10: $A$ angústia. Nele, a angústia é tida como efeito da presença do objeto $a$ no campo do Outro. E presença que abala, faz tremer as identificações do sujeito aos ideais do Outro/eu. Posteriormente, em seu ensino, Lacan retomará a angústia como efeito da presença da falta $(a)$ no discurso e, mais ainda, da falta no/do Outro $[S(\AA)]$. A via identificatória como meio para ser feito o final de análise é, portanto, tida por Lacan como um dos mais sérios desvios no campo ético da psicanálise. O desejo do psicanalista, "desejo sempre presumido, jamais definido, e que pode, por isso mesmo e a todo instante, acontecer nesse lugar do Outro, de onde surge para o analisante a angústia" (LACAN: 1960-1961/1990?b, lição 18 de 02/03/1961). Deduz-se daí que, na direção do tratamento, a identificação é uma via cômoda, na verdade uma defesa contra a angústia, à qual o psicanalista deveria se opor. E, mais ainda, que a angústia tem, com o desejo do psicanalista, uma grande proximidade topológica, proximidade essa marcada pela "presença do objeto $a$ no campo do Outro".
Ceder à identificação com o eu forte do psicanalista como meio de finalização do tratamento seria, então, para Lacan, no Seminário dedicado à angústia (LACAN, $1962-1963 / 2005$, p. 142-143), deixar o objeto $a$ absolutamente intacto. Seria domar a transferência através da identificação, sem, contudo, promover a sua destituição, ou seja, a destituição/desengano do sujeito-suposto-saber. Todavia, o posicionamento de Lacan diante dessa teoria sobre o final de análise sustentado na identificação com o psicanalista nos diz que, pelo contrário, a análise deveria, antes de tudo, fazer tremer os semblantes identificatórios - e jamais reforçá-los.

O que faz de uma psicanálise uma aventura singular é a busca de ágalma no campo do Outro. Interroguei-os diversas vezes sobre o que convém que seja o desejo do analista, a fim de que seja possível o trabalho ali onde tentamos levar as coisas além do limite da angústia. Certamente convém que o analista seja aquele que, minimamente, não importa por qual vertente, por qual borda, tenha feito seu desejo entrar suficientemente nesse $a$ irredutível para oferecer à questão do conceito da angústia uma garantia real (LACAN, 1962-1963/2005 p. 366).

E é com essas palavras - amparadas na localização da angústia entre o desejo e o gozo - que Lacan encerra o referido Seminário.

Já o Seminário 11: Os quatro conceitos fundamentais da psicanálise (LACAN, 1964/1979, p. 149) é marcado por várias formulações sobre o desejo do psicanalista "como lugar de junção do campo da demanda, onde se presentificam as síncopes do inconsciente, com a realidade sexual".

O que há de ser do desejo do analista para que ele opere de maneira correta? Pode esta questão ser deixada fora dos limites de nosso campo, como o é de fato nas ciências - as ciências modernas do tipo mais garantido - em que ninguém se interroga sobre o que é, por exemplo, do desejo do físico? O desejo do analista, em cada caso, não pode de modo algum ser deixado fora de nossa questão, pela razão de que o problema da formação do analista o coloca. E a análise didática não pode servir para outra coisa senão para levá-lo a esse ponto que designo em minha álgebra como o desejo do analista (LACAN, 1964/1979, p. 17).

Além de afirmar aí que o desejo do psicanalista surge como uma incidência essencial e única do desejo no campo da ciência moderna, neste mesmo Seminário Lacan se pergunta onde fica o ponto de disjunção e de conjunção, de união e de fronteira entre a psicanálise e a ciência, que só pode ser ocupado pelo desejo do psicanalista. E, para responder a essa pergunta, ele recorre uma vez mais ao conceito de pulsão, mais especificamente ao que ele próprio nomeou como "desmontagem da pulsão" (LACAN, 1964/1979, p. 153-164) a partir de Freud. Sua aposta é que o conceito freudiano de pulsão abriu a perspectiva para que fosse formulado o desejo, mais especificamente, o do psicanalista.

O desejo do analista não é um desejo puro. É um desejo de obter a diferença absoluta, aquela que intervém quando, confrontado com o significante primordial, o sujeito vem, 
pela primeira vez, à posição de se assujeitar a ele. Só aí pode surgir a significação de um amor sem limite, porque fora dos limites da lei, somente onde ele pode viver (LACAN, 1964/1979, p. 260).

É com essas palavras que Lacan encerra o Seminário dedicado aos quatro conceitos fundamentais da psicanálise: apontando para a produção do significante primordial - a ser chamado posteriormente de significante-mestre (S1) - e para o objeto a como fundamento do "amor sem limite", ou seja, como objeto em junção com campo do Outro e em disjunção com o campo do gozo.

Observamos que neste mesmo Seminário Lacan ainda nos diz insistentemente da importância do desejo e da transferência (como demanda de amor dirigida ao psicanalista) naquilo que concerne à função essencial do desejo do psicanalista.

Enquanto o analista é suposto saber, ele é suposto saber também partir ao encontro do desejo inconsciente. É por isso que eu digo que o desejo é o eixo, o pivô, o cabo, o martelo, graças ao qual se aplica o elemento força, a inércia, que há por traz do que se formula primeiro, no discurso do paciente, como demanda, isto é, a transferência. O eixo, o ponto comum desse duplo machado, é o desejo do analista, que eu designo aqui como a função essencial. E não me digam que, esse desejo, eu não o nomeio, pois é precisamente um ponto que só é articulável pela relação do desejo ao desejo. Essa relação é interna. O desejo do homem é o desejo do Outro (LACAN, 1964/1979, p. 222-223).

Portanto, tanto quanto o desejo do psicanalista, é justamente no intervalo entre os significantes, no intervalo entre $\mathrm{S} 1$ e S2, que Lacan localiza do objeto $a$ como falta/hiância que se liga ao desejo do Outro. Daí o fundamento da fórmula que fará do psicanalista "semblante do objeto $a$ ".

Transferência e engano são, portanto, os termos articulados por Lacan ao se referir uma vez mais, neste mesmo Seminário, ao desejo do psicanalista e à sua importância capital na direção do tratamento. Lacan, na verdade, retoma aqui o paradoxo da transferência, já presente desde Freud: como meio (amistosidade em colaborar com a execução da regra fundamental) e como obstáculo (resistência). Porém, Lacan (1964/1979, p. 239-240) destaca aí, nesse mesmo paradoxo, a inexorável presença do engano e da tapeação no amor de transferência:

Convém então apontar aqui o seguinte - que é sempre eludido, que Freud articula, e que não é desculpa, mas razão da transferência - que nada poderia ser atingido in absentia, in effigie. Isto quer dizer que a transferência não é, por sua natureza, a sombra de algo que tenha sido vivido antigamente. Muito ao contrário, o sujeito enquanto assujeitado ao desejo do analista deseja enganá-lo dessa sujeição, fazendo-se amar por ele, propondo por si mesmo essa falsidade essencial que é o amor. O efeito de transferência é esse efeito de tapeação no que ele se repete presentemente aqui e agora.

Ele só é repetição do que se passou assim-assim, por ter a mesma forma. Não é sombra das antigas tapeações do amor. É isolamento, no atual, de seu funcionamento puro de tapeação.

É por isso que, por trás do amor dito de transferência, podemos dizer que o que há é afirmação do laço do desejo do analista com o desejo do paciente. É o que Freud traduziu numa espécie de rápido escamoteamento, um chamariz, dizendo - "depois de tudo, é apenas o desejo do paciente" coisa para serenar os confrades. É desejo do paciente, sim, mas no seu encontro com o desejo do analista. Esse desejo do analista, não direi de modo algum que não o nomeei ainda, pois como nomear um desejo? Um desejo, o cercamos. Muitas coisas na história nos dão aqui traço e pista.

Convém aqui nos lembrarmos do artigo "O engano do sujeito suposto saber” (LACAN, 1967/2003). Este artigo é, na verdade, uma continuação do raciocínio presente na seção intitulada 'Da interpretação à transferência', presente no Seminário 11 (LACAN, 1964/1979). Nele, há a teorização no entorno do objeto $a$ e de sua participação no desejo e no ato do psicanalista. Sua argumentação, na verdade, já preparava o campo para a formalização da teoria dos discursos e de seus matemas (LACAN, 19691970/1992b), mais especificamente do discurso do psicanalista $\left(a / \mathrm{S}_{2} \rightarrow \$ / \mathrm{S} 1\right)$. Todavia o que aqui nos interessou foi a defesa acerca da posição do psicanalista como lugar consonante a sua prática e, por isso mesmo, lugar marcado pela falta inerente ao desejo $(a)$ e ao sujeito (\$). Referindo-se ao lugar do Deus-Pai, por ele designado como Nome-do-Pai, Lacan (1967/2003, p. 338) nos diz por que tal lugar não basta para abordar a posição do psicanalista:

De fato, é nesta relação hiante que fica suspensa a posição do psicanalista. Ele não é apenas solicitado a construir a teoria do engano essencial ao sujeito da teoria - aquele que chamamos de sujeito suposto saber. Uma teoria que inclua uma falta, a ser encontrada em todos os níveis, inscrevendo-se aqui como indeterminação, ali como certeza, e a formar o nó do ininterpretável, é nela que me empenho, decerto não sem experimentar sua atopia sem precedentes.

Sobre o fato de o psicanalista não poder jamais reduzir-se à representação e aos poderes daí decorrentes, em função de uma tradição "idealista" e "psicologizante", Lacan (1967/2003, p. 339) afirma:

Ora, é justamente na prática, antes de mais nada, que o psicanalista tem que se igualar à estrutura que o determina, não em sua forma mental, infelizmente! - é exatamente aí que está o impasse -, mas em sua posição de sujeito tal como inscrita no real: tal inscrição é o que define propriamente $\mathrm{o}$ ato. Na estrutura do engano do sujeito suposto saber, o psicanalista, no entanto, tem que encontrar a certeza de seu ato e a hiância que constitui sua lei.

A "posição de sujeito inscrita no ato" foi matemizada nos Seminários 15 (LACAN, 1967-1968/1992?) e 17 (LACAN, 1969-1970/1992b): $a \rightarrow \$$. Ela supõe que, durante o ato psicanalítico, o sujeito é agido pelo objeto, por isso o ato se faz sem pensar, ou seja, ele antecipa uma conclusão, cujo processo não foi, todavia, supervisionado e controlado pelo eu. Subordinar o sujeito ao ato foi, portanto, um artifício lacaniano para ir além do pai freudiano, para além do valor do pai e da castração na cultura.

Voltando ao Seminário 11 (LACAN, 1964/1979, p. 258259), outra referência digna de nota aponta, uma vez mais, para a antinomia desejo-interpretação, desejo-idealização: 
Para lhes dar fórmulas-referência, direi - se a transferência é o que, da pulsão, desvia a demanda, o desejo do analista é aquilo que a traz ali de volta. E, por essa via, ele isola o $a$, o põe à maior distância do I que ele, o analista, é chamado pelo sujeito a encarnar. É dessa idealização que o analista tem que tombar (se safar) para ser o suporte do $a$ separador, na medida em que seu desejo lhe permite, numa hipótese às avessas, encarnar, ele, o hipnotizado.

$\mathrm{O}$ esquema que the deixo como guia da experiência, como também da leitura, lhes indica que a transferência se exerce no sentido de reconduzir a demanda à identificação. É na medida em que o desejo do analista, que resta um $x$, tende para um sentido exatamente contrário à identificação, que a travessia do plano da identificação é possível, pelo intermédio da separação do sujeito na experiência. A experiência do sujeito é assim reconduzida ao plano onde se pode presentificar, da realidade do inconsciente, a pulsão.

Reencontrar a lógica pulsional no final de análise, mais especificamente a demanda de satisfação inerente à pulsão, é então a decorrência lógica da separação sujeito-objeto promovida pelo processo psicanalítico. Nesse processo, a extração do objeto $a$ do campo do Outro é necessária para que o psicanalista não ceda à demanda de se oferecer como suporte identificatório ao psicanalisante. Pelo contrário, é pelo fato de o psicanalista declinar desse lugar do ideal [I(A)] que o psicanalisante é forçado a ter de se haver com o seu ser-de-objeto - ser este que, partindo da fonte, circula o objeto e a ela retorna, nos moldes do circuito da pulsão.

Aqui observamos que, se as principais referências de Lacan ao desejo do psicanalista são ainda incipientes nos Seminários 6 e 7, nos Seminários seguintes, até o Seminário 12, elas são abundantes, sendo que seu ápice é atingido, sem dúvida, no Seminário 11. Neste último, tais referências perpassam a abordagem de todos os quatro conceitos fundamentais da psicanálise (inconsciente, pulsão, repetição e transferência).

As relações do desejo com a identificação são examinadas por Lacan principalmente no Seminário 9, dedicado à identificação. Lacan aí considerou as coordenadas já estabelecidas por Freud, ou seja, que entre esses dois conceitos há uma área de interseção e, antes de tudo, a tendência à subordinação radical da identificação ao desejo do Outro e a seus ideais (I[A]). E esta tendência, ancorada no nome próprio ao qual o sujeito se identifica, caminha na direção contrária à destituição subjetiva decorrente do processo analítico. De modo que, se por um lado o sujeito tem ancorada a sua formação nas identificações com os ideais do Outro, por outro a destituição subjetiva implica a queda de algumas identificações secundárias $(\mathrm{S} 2)$ e o sério abalo ou tremor das identificações primárias (S1), dentre elas a identificação com o nome e com o corpo próprios. Com Freud, Lacan ainda aprendeu que a identificação, enquanto sustentada nos registros Imaginário e Simbólico, só ocorre em função de uma perda de gozo ocorrida a partir do Real. A extração do objeto $a$ do campo do Outro abriu para Lacan não somente a perspectiva ao desejo, como também, por decorrência, à identificação.
Por isso Lacan (1964-1965/1990?c), também no Seminário 12 , nos diz que o desejo do psicanalista precisa ser diferenciado topologicamente do fenômeno da identificação. E essa diferenciação não é sem importância, pois nos traria a marca de duas concepções distintas do final de análise: o final de análise sustentado na identificação com o eu forte do psicanalista, e o final de análise sustentado na destituição da transferência ou, em outros termos, na queda ou desengano do sujeito suposto saber. No primeiro caso, há a manutenção intacta da neurose de transferência, o que levou Lacan a dizer que "a neurose de transferência é a neurose do psicanalista. Se refugia na transferência na medida em que não se está no ponto quanto ao desejo do psicanalista" (LACAN, 1964-1965/1990?c, lição 8 de 03/02/1965). O risco de o psicanalista compactuar com a neurose de transferência culminaria, inevitavelmente, no que se chama classicamente de análise interminável ou sem fim. Por isso, a neurose de transferência

[...] é imbatível justamente porque, não havendo solução para ela, a astúcia do condutor do jogo - se o analista merece seu nome - não pode ser mais que isto: de fazer culminar dela, de depreender dessa defesa, uma forma sempre mais pura. É este o desejo do analista na operação: levar o sujeito a seu fantasma fundamental, e isso não é ensinar-lhe nada, é aprender com ele como fazê-lo. O objeto $a$ e sua relação com um caso determinado, e aí a divisão do sujeito - isso é o paciente que sabe fazer ali. E nós estamos no lugar do resultado, na medida em que o favorecemos. O analisado é o lugar em que isso se verifica de um modo radical, porque aqui se mostra a superposição estrita que designa o desejo do Outro, não porque ao paciente lhe seja ditado o desejo do analista, mas porque o analista se fez o desejo do paciente. Qual deve ser o desejo do analista, para sustentar-se por sua vez neste ponto de suprema cumplicidade, cumplicidade aberta à surpresa? (LACAN, 1964-1965/1990?c, lição de 19/05/1965).

\section{E ele prossegue ao responder que}

O oposto desta espera onde se constitui o jogo em si, o jogo como tal, é o inesperado. $\mathrm{O}$ inesperado não é o risco. Um se prepara ao inesperado. O inesperado mesmo - se me permitem por um instante voltar sobre este esboço da estruturação para-euleriana que lhes dei como necessário a certos conceitos, o oito invertido, esta banda de Möebius, que deve atravessar a pulsão oculta. Que é o inesperado senão o que se revela como espera já esperada, mas só quando chega? O inesperado atravessa o campo do esperado ao redor desse jogo da espera - e é fazendo frente à angústia ao redor do campo da espera, como Freud, nos textos fundamentais sobre esse tema já havia formulado (LACAN, 1964-1965/1990?c, lição de 19/05/1965).

Daí concluirmos que o inesperado já esperado, porém ainda não vivido pelo sujeito, é, no contexto da vida, a morte, e, no contexto da cura, o ato de finalização do tratamento psicanalítico. Quando chega ao final de análise, o sujeito, principalmente ao não se refugiar na identificação com o psicanalista, além de ter de se haver com o incurável de seu sintoma, tem de se haver com os enganos que ali o levaram, dentre eles o engano do sujeito suposto sa- 
ber. Aí, graças ao ser-de-objeto $(a)$, abre-se a perspectiva ao des-ser do psicanalista, verdadeiro núcleo do desejo do psicanalista ao redor do qual gira a ética da psicanálise.

Portanto, no Seminário 12 duas posições opostas já estão demarcadas por Lacan quanto ao final de análise: 1- a do refúgio na transferência pela via da identificação com o psicanalista, em que o sujeito suposto saber é mantido intacto e, exatamente por isso, a transferência e o tratamento permanecem sem fim; 2- a da destituição da transferência e do desengano do sujeito suposto saber como efeitos inevitáveis da redução do psicanalista à função de objeto $a$.

No Seminário dedicado ao ato do psicanalista, há a afirmação categórica de que, no final da análise, o sujeito suposto saber, função esta evocada no início do processo analítico, fica reduzido ao "[...] 'não estar/ser aí' que é o que é característico do próprio inconsciente, e que esta descoberta faz parte da mesma operação verdade" (LACAN, 1967-1968/1992?, p. 90-91). A redução do psicanalista à condição de resto ou resíduo da operação analítica $(a)$ traria à tona a transformação do "sujeito suposto saber" em "significante que falta ao Outro" $[S(\AA)]$. Por meio do desejo do psicanalista, como um leme a conduzir a cura, o Outro é desvanecido e, de seu campo, é arrancado o objeto $a$. O "não estar/ser aí" do psicanalista - uma vez que este já esteja desapossado da condição agalmática e, por isso mesmo, seja como tal tomado como lixeira - mostrou a Lacan que, tanto quanto o objeto $a$, o ser do psicanalista é ser sem essência. Entretanto, este ser sem essência ( $a$ ) é o mesmo que, no lugar de causa, pôs em movimento o processo analítico $(a \rightarrow \$)$, e que agora, enquanto resto projetado/lançado sobre o psicanalista, aponta para a sua finalização.

E é com este argumento, nesse mesmo Seminário, que Lacan aproxima o "desejo do psicanalista" do "ato do psicanalista". Além de o ato do psicanalista produzir um psicanalista - e mais ainda pelo fato de o sujeito suposto saber não ser um sujeito que esteja no ato, inclusive o de finalização ${ }^{3}$-, Lacan usa a expressão "sujeito do ato" para se referir à passagem de psicanalisante à psicanalista. Segundo ele, o objeto $a$, "Objeto sem essência que são, ou não, reevocados no ato a partir dessa espécie de sujeito que, como veremos, é o sujeito do ato; diria, uma vez que, como sujeito suposto saber, é um sujeito que não está no ato, ao final da experiência analítica" (LACAN, 1967-1968/1992?, p. 91).

Portanto, o desejo do psicanalista, expressão que, como vimos, já era usada por Lacan anteriormente, passa, com o estatuto do ato, à condição de coordenada marcante do final de análise. De modo que a passagem de psicanalisante à psicanalista, inerente ao ato do psicanalista, herdou as formulações anteriores destinadas ao desejo do psicanalista. $\mathrm{O}$ ato do psicanalista se mostrou aqui uma versão ampliada do desejo do psicanalista.

\footnotetext{
${ }^{3}$ Lembremos aqui a máxima presente neste Seminário, qual seja, que sujeito e

ato se excluem.
${ }^{4}$ Talvez fosse mais cabível a expressão "sujeito ao ato" do que "sujeito do ato", já

ato se excluem.
${ }^{4}$ Talvez fosse mais cabível a expressão "sujeito ao ato" do que "sujeito do ato", já que há entre eles uma relação de exclusão: ou o sujeito ou o ato.
} Fractal, Rev. Psicol., v. 32 - n. 1, p. 12-20, 2020
O desejo do psicanalista é, portanto, o que opera na psicanálise para além da terapêutica, para além da transferência e para muito além da identificação, compondo desse modo a formação do psicanalista, principalmente na vertente intensiva.

Concluímos aqui que tal formação passa necessariamente pelo engano do sujeito suposto saber, verdadeiro pivô da transferência, e que, todavia, culmina no desejo do psicanalista. Da transferência ao desejo do psicanalista é então o percurso por meio do qual Lacan pensa o final de análise, com a consequente produção de um psicanalista. E a advertência lacaniana de que o psicanalisante deve se haver, no final, com a falta de essência que caracteriza o objeto $a$, e, por consequência, o seu ato $(a \rightarrow \$)$, deve aqui ser destacada.

Propondo-se a manter a visão sempre aberta à questão do desejo do psicanalista, Lacan (1960/1998b, p. 839) se pergunta - e aos leitores/psicanalistas:

[...] como deve o analista preservar para o outro a dimensão imaginária de sua não-dominação, de sua imperfeição necessária, eis o que é tão importante estabelecer quanto o fornecimento, nele voluntário, de sua inciência quanto a cada sujeito que vai procurá-lo em análise, de sua ignorância sempre renovada de que alguns deles constituam um caso.

Portanto, a não-dominação, a imperfeição necessária e a inciência do psicanalista são algumas características de seu desejo que nos estimulam a jamais perder a perspectiva da falta inerente ao sujeito, ao desejo e ao Outro. É essa a posição que Lacan adota abertamente no que diz respeito à condução das análises, ou seja, à ética da psicanálise e a seu operador elementar aqui destacado, o desejo do psicanalista. E esta condução é nitidamente marcada pela posição que o psicanalista a si mesmo coloca: destituído como sujeito e, por isso mesmo, aberto para ser tomado como objeto causa do desejo.

O "desejo do psicanalista", portanto, revelou-se, no ensino de Lacan, como uma designação pertinente ao que se transmite em psicanálise. Principalmente porque o psicanalista é, por meio de seus atos (do início ao fim de uma psicanálise), aquele que, na situação analítica e calcado na política da falta-a-ser, aponta para o psicanalisante a ex-sistência do objeto $a$, e, desse modo, a impropriedade de qualquer saber totalizante e suficiente acerca de si mesmo. Colocar-se como semblante do objeto $a$-inicialmente suportando ser tomado como sujeito suposto saber e, ao final, ser tomado como dejeto/resto do processo é, portanto, a sua função, principalmente ao agir como operador da "ética do desejo" ou "ética do bem-dizer" a partir do sintoma e da transferência.

Daí concluirmos que toda a perspectiva ética do ensino de Lacan buscou, no objeto $a$, um modo de atribuir um lugar e, assim, consistência lógica ao registro do real. E o desejo do psicanalista também nos deu mostras de ser uma expressão pertinente ao registro do real, por meio da formulação do objeto $a$. A ausência de essência desse objeto e sua operacionalização no desejo do psicanalista demonstraram-nos, ainda, existir uma coerência entre o desejo do psicanalista e sua política, a política da falta-a-ser. 
Portanto, a transmissão em/da psicanálise é concomitante à direção dada ao tratamento, ou seja, o psicanalista a promove em função do modo como se engaja na direção da cura. E se o estilo, no sentido lato, é uma marca singular de inscrição real de um sujeito no campo da cultura, nos perguntamos: como ele se faz presente na situação analítica? Seguramente, o desejo do psicanalista - ou seja, o que foi a sua experiência de destituição subjetiva coadunada com os princípios e conceitos da psicanálise - imiscui-se no tratamento ao fazer existir aí, singularmente, o inconsciente.

Com a formulação do objeto $a$ como o eixo em torno do qual giraria o desejo do psicanalista, Lacan tentou, ainda, neutralizar o risco de a formação do psicanalista se ver reduzida à dimensão do sentido, ou seja, tornar-se mero jogo de palavras sem efeitos sobre o sujeito, tornando assim o psicanalisante prisioneiro do gozo do sentido.

O desejo do psicanalista em seu núcleo elementar, o objeto $a$ - como desejo inédito inventado por Freud - nos mostrou, ainda, seu paradoxo elementar: sua posição de metáxi: entre verdade e saber, entre a a-língua (singularidade absoluta) e a Língua (como código social), entre a inconsistência do Outro, demonstrada pelo atravessamento da fantasia fundamental, e a consistência lógica do objeto $a$; entre os recursos-padrão (estilísticos) disponibilizados pelo Outro e pelo que lhe falta $[S(\mathbb{A})]$.

De modo que a expressão "desejo do psicanalista" se mostrou digna de nota e mesmo de notação, justo por assinalar e apontar para a dimensão ética da psicanálise, ou seja, para as vias de transmissão a partir da prática do psicanalista, principalmente ao chamá-lo à responsabilidade como o seu operador ético essencial.

\section{Informações sobre o autor}

\section{Julio Eduardo de Castro \\ (iD) https://orcid.org/0000-0001-7570-1037

É psicanalista e professor titular aposentado da Universidade Federal de São João del Rei (UFSJ). Possui graduação em Psicologia pela Universidade Católica de Minas Gerais, mestrado em Educação pela Pontifícia Universidade Católica do Rio de Janeiro, doutorado em Teoria Psicanalítica pela Universidade Federal do Rio de Janeiro e pós-doutorado em Psicologia pela PUC-Minas (2012).

\section{Como citar este artigo:}

\section{ABNT}

CASTRO, Júlio Eduardo de. O desejo do psicanalista como operador ético da psicanálise. Fractal: Revista de Psicologia, Niterói, v. 32, n. 1, p. 12-20, jan./abr. 2020. https://doi.org/10.22409/1984-0292/ v32i1/5628

\section{APA}

Castro, J. E. (2020, Janeiro/Abril). O desejo do psicanalista como operador ético da psicanálise. Fractal: Revista de Psicologia, 32(1), 12-20. doi: https://doi.org/10.22409/1984-0292/v32i1/5628

\section{Referências}

CASTRO, Julio Eduardo de. Consequências éticas da teoria lacaniana dos discursos no ensino da psicanálise. 2006. Tese (Doutorado)-Programa de Pós-Graduação em Teoria Psicanalítica, Universidade Federal do Rio de Janeiro, Rio de Janeiro, 2006.

LACAN, J. O Seminário: os quatro conceitos fundamentais da psicanálise (1964). Rio de Janeiro: J. Zahar, 1979. livro 11.

LACAN, Jacques. O Seminário: a ética da psicanálise (19591960). Rio de Janeiro: J. Zahar, 1988. livro 7.

LACAN, Jacques. O Seminário: o desejo e sua interpretação (1959-1960). Buenos Aires: Escola de Psicanálise de Buenos Aires, [1990?a]. livro 6. Edição Eletrônica em CD-ROM dos Seminários e Escritos de Jacques Lacan. Não paginado.

LACAN, Jacques. O Seminário: a identificação (1960-1961). Buenos Aires: Escola de Psicanálise de Buenos Aires, [1990?b]. livro 9. Edição Eletrônica em CD-ROW dos Seminários e Escritos de Jacques Lacan. Não paginado.

LACAN, Jacques. O Seminário: problemas cruciais para a psicanálise. (1964-1965). Buenos Aires: Escola de Psicanálise de Buenos Aires, livro 12. Edição Eletrônica em CD-ROW dos Seminários e Escritos de Jacques Lacan [1990?c]. Não paginado.

LACAN, Jacques. O Seminário: a transferência (1960-1961). Rio de Janeiro: J. Zahar, 1992a. livro 8.

LACAN, Jacques. O Seminário: o avesso da psicanálise (19691970). Rio de Janeiro: J. Zahar, 1992b. livro 17.

LACAN, Jacques. O Seminário: o ato psicanalítico (19671968). [S.1.: s.n., 1992?]. livro 15.

LACAN, Jacques. A direção do tratamento e os princípios de seu poder (1958). In: 1998a. p. 591-652. . Escritos. Rio de Janeiro: J. Zahar,

LACAN, J. Subversão do sujeito e dialética do desejo no inconsciente freudiano (1960). In: Janeiro: J. Zahar, 1998b. p 807-842. . Escritos. Rio de

LACAN, Jacques. Do "Trieb" de Freud e do desejo do psicanalista (1964). In: . Escritos. Rio de Janeiro: J. Zahar, 1998c. p. 865-868.

LACAN, Jacques. O engano do sujeito suposto saber (1967). In:__. Outros Escritos. Rio de Janeiro: J. Zahar, 2003. p. $329-340$.

LACAN, J. O Seminário: a angústia (1962-1963). Rio de Janeiro: J. Zahar, 2005. livro 10. 